\title{
The Correlation between Leadership Style of Principals and Job Satisfaction of High School Teachers in Region 1, Zanjan, Iran
}

\author{
Masume Shahidi \\ Ministry of Education, Zanjan, Iran
}

\begin{abstract}
The job satisfaction is a complex and multidimensional concept and is associated with psychological, physical, and social factors. There are various factors affecting the job satisfaction. However, this study aimed to investigate the correlation between leadership style of principals and job satisfaction of high school teachers in region 1, Zanjan. This was descriptive-correlational study. The population consisted of all high school teachers in Region 1, Zanjan in 2015-2016 ( $\mathrm{N}=380)$. Using Morgan table, the sample size was determined to be 181 subjects; the participants were selected randomly. Two standardized questionnaires were used for collecting the data: Likert's Principals' Leadership Styles Questionnaire (2000) and Minnesota's Job Satisfaction Questionnaire (1967). Using Cronbach's alpha, the reliability of these questionnaires was determined to be 0.83 and 0.84, respectively. Using SPSS Software, the descriptive and inferential statistics were used for analyzing the data. The findings showed that there was significant positive correlation between consultative and participative leadership style of principals and job satisfaction of teachers.
\end{abstract}

Keywords: Leadership Styles, Job Satisfaction, Principals, High School Teachers, Region 1, Zanjan

\section{INTRODUCTION}

In early twenty-first century, the education and training is an important part of personal and social activities. According to UNESCO, from every five people, one is student or teacher in formal education system (UNESCO World Report, quoted by Salehpour 2011, p. 191). The self-sufficiency and independence of societies relies on their educational organizations. Among all effectiveness factors of educational organizations, most educational issues' experts and scholars believe that the teachers are the most important factor in education process. Therefore, considering their needs and meeting them may be resulted in employees' job satisfaction and their favorable organizational commitment (Pat, quoted by Salehpour 2011, p. 191). In many countries, the undesirable situation of teachers have led to turnover and absenteeism of them (Soroush, quoted by Salehpour, 2011, p. 191). However, all countries need efficient education and training system to develop comprehensively. To have successful and efficient educational staff, the first step is understanding the factors which impact on quality of teachers' performance; there is direct relationship between job satisfaction and performance of individuals. The satisfied people perform better their tasks and the dissatisfied people do not perform their job properly (Mohammadi Asl, 2010, p. 22). On the other hand, one of the factors affecting the success of organization in achieving the goals is the manager's leadership style. The manager, as the leader of organization may adopt different styles in directing human resources. The proper behavioral patterns of managers at each organization may create strong morale and motivation in employees and increase their job satisfaction. However, numerous studies have shown the important impact of leadership style on employee satisfaction. For example, Ohio researchers found that if leaders adopt the task-oriented leadership style, the employees will have better performance and high satisfaction. Blake and Mouton concluded that the leaders who adopt team style are more successful than the leaders who adopt other styles. Also, Hooper and Potter (1997) studied the variables of top leaders (direct direction, effective communication, being role model for employees, etc.) and concluded that these factors complete and increase effectively the ability to support emotionally the followers (Quoted by Tadbiri, 2013, p. 68). Considering the importance of leadership and management in schools and the importance of job satisfaction of teachers as key elements of school, this study aims to investigate the correlation between leadership style of principals and job satisfaction of high school teachers in region 1, Zanjan. In this regard, the research questions are as follows: 
1. Is there significant correlation between consultative leadership style and job satisfaction of high school teachers in region 1, Zanjan?

2. Is there significant correlation between participative leadership style and job satisfaction of high school teachers in region 1, Zanjan?

\section{METHODOLOGY}

This was descriptive-correlational study. The population consisted of all high school teachers in Region 1, Zanjan in 2015-2016 ( $\mathrm{N=380).} \mathrm{Using} \mathrm{Morgan} \mathrm{table,} \mathrm{the} \mathrm{sample} \mathrm{size} \mathrm{was} \mathrm{determined} \mathrm{to} \mathrm{be}$ 181 subjects; the participants were selected randomly.

Two standardized questionnaires were used for collecting the data: Likert's Principals' Leadership Styles Questionnaire (2000) and Minnesota's Job Satisfaction Questionnaire (1967). Using Cronbach's alpha, the reliability of these questionnaires was determined to be 0.83 and 0.84 , respectively. Using SPSS Software, the descriptive and inferential statistics were used for analyzing the data.

\section{FINDINGS}

\section{Demographic Characteristics}

According to findings, 1, 95 (52.5\%) subjects are female and 86 (47.5\%) subjects are male. Therefore, most of the respondents are women.

According to figure 2, 17 (9.4\%) subjects are single and 164 (90.6\%) subjects are married. Therefore, most of the respondents are married.

According to table 1, $113(62.4 \%)$ subjects have bachelor degree, $63(34.8 \%)$ subjects have master degree, and $5(2.8 \%)$ subjects have $\mathrm{PhD}$ degree. Therefore, most of the respondents have bachelor degree.

Table1. Frequency of sample in terms of education degree

\begin{tabular}{|l|l|l|l|}
\hline Education level & Frequency & Frequency percentage & Cumulative percentage \\
\hline Bachelor & 113 & 62.4 & 62.4 \\
\hline Master & 63 & 34.8 & 97.2 \\
\hline PhD & 5 & 2.8 & 100.0 \\
\hline Total & 181 & 100.0 & \\
\hline
\end{tabular}

Hypothesis Test

First hypothesis: There is correlation between consultative leadership style of principals and job satisfaction of high school teachers in region 1, Zanjan.

Table 2: Correlation coefficient between principals' consultative leadership style and teachers' job satisfaction

\begin{tabular}{|l|ll|}
\hline Teachers' job satisfaction & & \\
\hline 0.558 & Pearson correlation coefficient & Consultative leadership \\
style
\end{tabular}

The Pearson correlation test showed that the correlation coefficient between consultative leadership style of principals and job satisfaction of teachers is significant at level of 5\%. According to participants, there is significant positive correlation between consultative leadership style of principals and job satisfaction of teachers. Therefore, if principals adopt consultative leadership style, the teachers' job satisfaction will increase, and vice versa.

\section{Normality of Variables Distribution in First Hypothesis}

The mean and standard deviation can be seen in right side of figure. This figure shows that the variables have almost normal distribution with a mean of 3.59 and standard deviation of 0.70.

Second hypothesis: There is correlation between participative leadership style of principals and job satisfaction of high school teachers in region 1, Zanjan. 


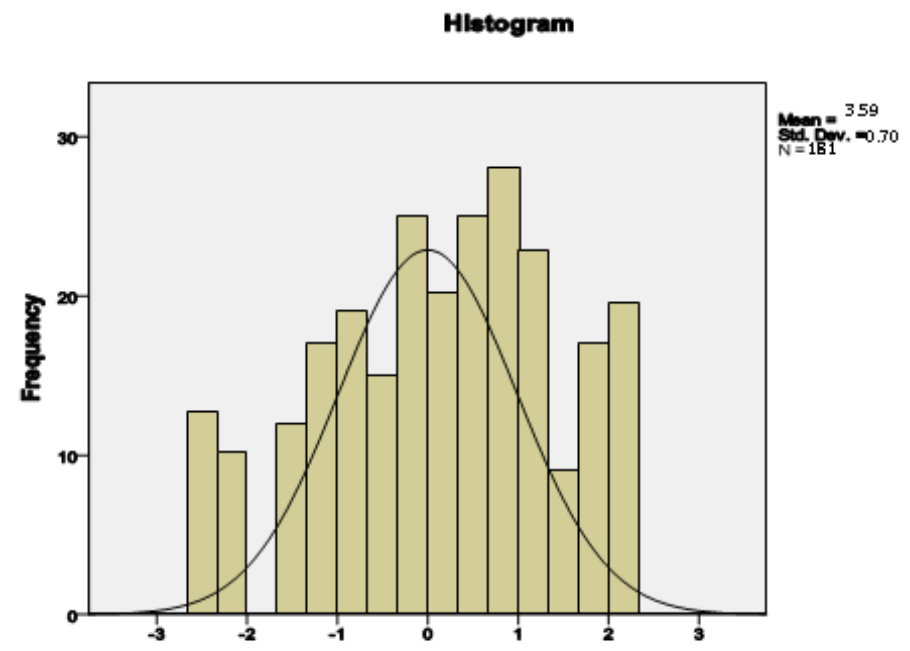

Table3. Correlation coefficient between principals' participative leadership style and teachers' job satisfaction

\begin{tabular}{|c|c|c|}
\hline Teachers' job satisfaction & & \\
\hline 0.535 & Pearson correlation coefficient & \multirow[t]{3}{*}{ Participative leadership style } \\
\hline 0.000 & Two-sided significance level & \\
\hline 181 & Sample size & \\
\hline
\end{tabular}

The Pearson correlation test showed that the correlation coefficient between participative leadership style of principals and job satisfaction of teachers is significant at level of 5\%. According to participants, there is significant positive correlation between participative leadership style of principals and job satisfaction of teachers. Therefore, if principals adopt participative leadership style, the teachers' job satisfaction will increase, and vice versa.

Normality of Variables Distribution in Second Hypothesis

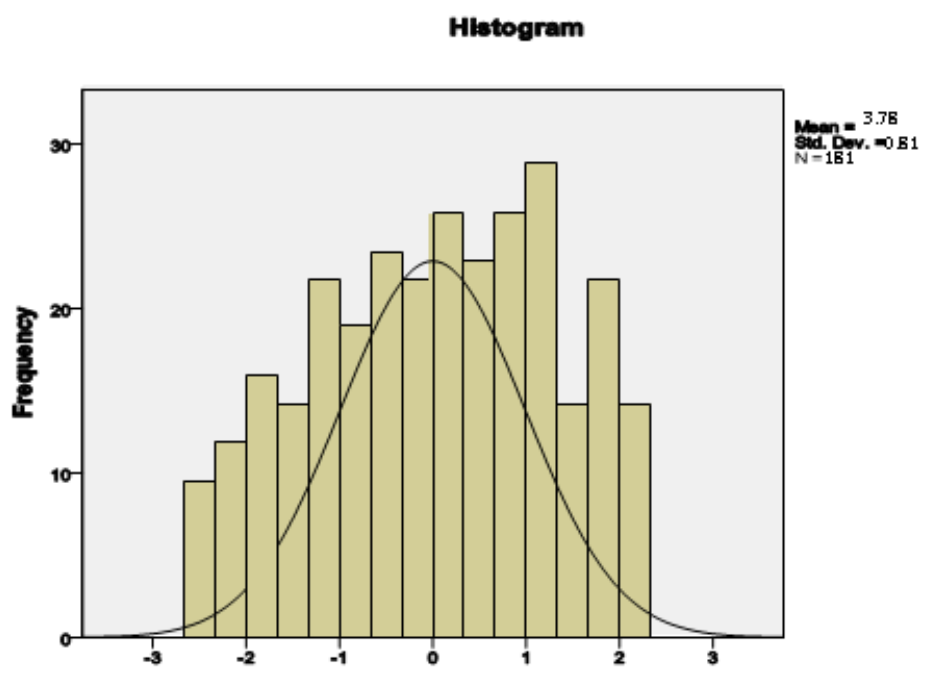

The mean and standard deviation can be seen in right side of figure. This figure shows that the variables have almost normal distribution with a mean of 3.78 and standard deviation of 0.81 .

Table4. Multiple regression analysis to predict job satisfaction of teachers through consultative and participative leadership styles

\begin{tabular}{|l|l|l|l|l|l|}
\hline $\begin{array}{l}\text { Criterion } \\
\text { variable }\end{array}$ & Predictor variables & $\begin{array}{l}\text { Non-standard } \\
\text { coefficients (B) }\end{array}$ & $\begin{array}{l}\text { Standard } \\
\text { coefficient (Beta) }\end{array}$ & T & Sig. level \\
\hline \multirow{2}{*}{$\begin{array}{l}\text { Job } \\
\text { satisfaction }\end{array}$} & Constant value & 60.214 & ---- & 6.317 & 0.000 \\
\cline { 2 - 6 } & Consultative & 0.925 & 0.226 & 2.133 & 0.034 \\
\cline { 2 - 6 } & Participative & -0.268 & 0.072 & 0.676 & 0.000 \\
\hline
\end{tabular}


According to multiple regression analysis results and F-value in above table, there is significant correlation between leadership style components of principals and job satisfaction of teachers; at least one of the regression coefficients is significant. In other words, the job satisfaction of teachers may be predicted based on the mentioned components. One unit change in standard deviation of consultative leadership style may change 0.226 standard deviation of job satisfaction of teachers and one unit change in standard deviation of participative leadership style may change 0.072 standard deviation of job satisfaction of teachers.

\section{CONCLUSION}

According to findings, $95(52.5 \%)$ subjects are female and 86 (47.5\%) subjects are male. Therefore, most of the respondents are women. According to findings, $17(9.4 \%)$ subjects are single and 164 $(90.6 \%)$ subjects are married. Therefore, most of the respondents are married. According to findings, $113(62.4 \%)$ subjects have bachelor degree, 63 (34.8\%) subjects have master degree, and $5(2.8 \%)$ subjects have $\mathrm{PhD}$ degree. Therefore, most of the respondents have bachelor degree.

The Pearson correlation test showed that the correlation coefficient between consultative leadership style of principals and job satisfaction of teachers is significant at level of 5\%. According to participants, there is significant positive correlation between consultative leadership style of principals and job satisfaction of teachers. Therefore, if principals adopt consultative leadership style, the teachers' job satisfaction will increase, and vice versa.

The Pearson correlation test showed that the correlation coefficient between participative leadership style of principals and job satisfaction of teachers is significant at level of 5\%. According to participants, there is significant positive correlation between participative leadership style of principals and job satisfaction of teachers. Therefore, if principals adopt participative leadership style, the teachers' job satisfaction will increase, and vice versa.

\section{REFERENCES}

[1] Pardakhtchi, M.H. (2005). Educational management as a professional field. Journal of management in education and training. Issue 3.

[2] Desler, G. (2008). Management Basics. Translated by Davood Madani. Volume II, Tehran: Arian.

[3] Delavar, A. (2010). Methodology in Psychology and Education Science.

[4] Davis, K., New Strom, J. (2007). Human behavior at work (organizational behavior). Translated by Mohammad Ali Tusi. Tehran: Public Management Training Center.

[5] Rezaeian, A. (2009). Organizational Behavior Management. Second Edition. Tehran: Samt.

[6] Saatchi, M. (2006). Psychology of work, organization, and management. First edition. Tehran: Public Management Training Center.

[7] Sarmad, G.A. (2009). Human relationships in educational organizations. First edition. Tehran: Samt.

[8] Shafi abadi, A. (2006). Career guidance and counseling. Sixth edition. Tehran: Roshd. 